\title{
Intellectual Capital, Corporate Social Responsibility, and Good Corporate Governance on Banking Financial Performance in Indonesia
}

\author{
Sigit Hermawan*, Aisha Hanif, Sarwenda Biduri, Nurasik, Puput Wijayanti \\ Accounting Department \\ Universitas Muhammadiyah Sidoarjo \\ Sidoarjo, Indonesia \\ *sigithermawan@umsida.ac.id, aishanif.umsida@gmail, sarwendabiduri@umsida.ac.id, \\ nurasik@umsida.ac.id,wijayanti.puput96@gmail.com
}

\begin{abstract}
This study aims to determine the effect of intellectual capital (IC), corporate social responsibility (CSR), and good corporate governance (GCG) on banking financial performance in Indonesia. The sampling method used was the purposive sampling method. The number of companies sampled in this study was 15 banking companies listed on the Indonesian Stock Exchange (IDX). The data used are secondary. The data analysis method used in this study is Multiple Linear Regression. The results of this study indicate that IC, CSR, and GCG has a partial and simultaneous effect on financial performance in banking companies listed on the IDX.
\end{abstract}

Keywords-intellectual capital, corporate social responsibility, good corporate governance, and financial performance

\section{INTRODUCTION}

Today, the era of technological globalization and intense competition forces companies to change the strategies applied in running businesses. The development of the business field towards a knowledge-based business is not only determined by physical assets but also based on the quality of the company's resources such as knowledge, expertise, innovation owned by workers (Intellectual Capital). Intellectual Capital as an intangible asset has been proven to be able to improve performance, competitiveness and welfare [1-4]. It requires the company to provide a larger portion of the use of intangible assets. According to the resource-based theory, a company will have good corporate values by owning control and utilizing strategic assets (tangible and intangible assets). It must also be supported by quality and good corporate governance (Good Corporate Governance). According to the study results, it is said that corporate governance is a concept proposed to improve company performance through supervision or monitoring of management performance and to ensure management accountability to stakeholders based on a regulatory framework [5].

As part of the modern business world, Intellectual Capital and Good Corporate Governance are precious bank strategies.
Because for the banking sector being an intellectually incentive business sector, and it also includes the service sector, where customer service relies heavily on human capital intellectuals/intelligence, banking is also one of the industries that fall into the knowledge-based industry category. Industries), an industry that takes advantage of the innovations it creates to provide its value for the products and services produced for consumers. According to overall, employees in the banking sector are also more homogeneous intellectually than in other industrial sectors.

Corporate Social Responsibility is essential for the company because it is a form of company concern that wants to survive in the long term. The company must be involved in fulfilling stakeholders' welfare and contribute to preserving the environment, which is often termed the Triple Bottom Line concept. The concept of triple bottom Line Reporting is a concept that includes three dimensions, namely the social dimension (people), the dimension of the environment (planet), and the economic dimension (profit) [6]

Initially, CSR was based on philanthropic activities, namely humanitarian encouragement that came from universal norms and ethics to help others and fight for social equity [7]. Nowadays, CSR has been used as a strategy by companies to improve the company's image, which will affect the company's financial performance. This CSR-oriented company has come up with many new concepts known as corporate citizenship [8].

In addition to increasing the quality of governance system resources, it is also crucial for banks. Banks must be managed in a professional, modern, and following their objectives. Along with the development of existing banking management, the bank's function has become broader and has a central role in economic and business development; trust is a significant factor in allocating one's funds to the bank. Meanwhile, many banks are still exercising this trust, causing losses to customers, and decreasing customer confidence. The cause of consumer distrust occurs when there is a lack of corporate banking 
governance or what is commonly known as Good Corporate Governance. For this reason, Good Corporate Governance is needed in building public and international trust as an absolute requirement for the banking world to develop correctly and healthily.

In this study, ROA is the basis for measuring financial performance. ROA is used to measure the company's ability to generate operating profits with total existing assets. ROA tries to measure the effectiveness of the company [9]. The level of ROA indicates the efficiency of using capital and the fluctuation of income. In this study, the authors use ROA because ROA is easy to understand, namely by comparing net income with assets.

ROA is an indicator of a company's success in obtaining profits so that the higher the profitability, the higher the ability to earn profits for the company [10]. Therefore, this research tries to measure the banking sector's performance because it is crucial in the process of economic development. Besides, the banking sector is a business sector that is "intellectually incentive" and includes the service sector that depends on human resources' intellect/intellect/intelligence [8]. The banking industry is an industry that makes sense in the knowledge category, specifically utilizing innovations that provide value to service products provided to consumers [11].

Based on the above background, in which the implementation of company development demands good corporate governance, social responsibility is both internal and external plus the value of developing knowledge management. Therefore, the authors are motivated to study "The Influence Intellectual Capital, Corporate Social Responsibility, and Good Corporate Governance on Financial Performance on Banking Financial Performance in Indonesia 2012-2016".

\section{METHODS}

\section{A. Research Approach}

This research uses quantitative research. A quantitative research focuses on the existence of variables as the study's object, and these variables must be defined by the form of operationalization of each variable [12].

In this study, the sample collection technique used judgment sampling, commonly known as purposive sampling. The definition of purposive sampling is the sample's determination by considering the criteria that have been determined by the researcher [13]

\section{B. Research Design}

Starting with the title, the formulation of the problem, the research objectives, the hypothesis, and the data consists of selecting population and sample data, then testing the data, discussing it, after that, conclusions and suggestions.

\section{Operational Definition and Variable Indicators}

1) Intellectual capital: Intellectual capital is the company's overall dimensions, namely customer relations, company workforce, and supporting procedures created by innovation, modification of current knowledge, transfer of knowledge, and continuous learning, which ultimately can improve company performance and value [14].

The proxy used to measure intellectual capital in this study uses the ValueAdded Intellectual Coefficient (VAIC ${ }^{\mathrm{TM}}$ ) method developed by Pulic, Ante [15]

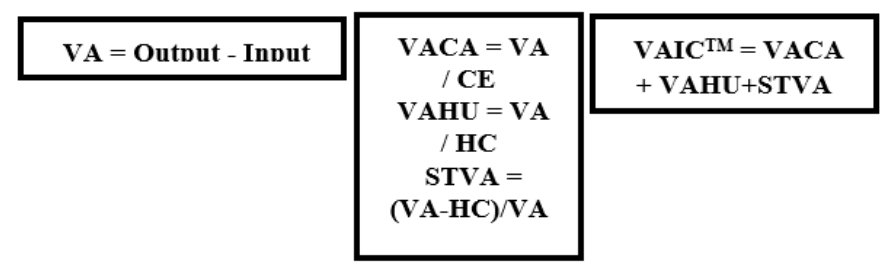

2) Corporate social responsibility: CSR can be measured by looking at the number of social disclosure items in the company's annual report. The proxy used to measure the Global Reporting Initiative (GRI) standard CSR is the standard for disclosure Corporate Social Responsibility in Indonesia.

If the company that provides social disclosure is given a score of one (1), but if it does not, then it is given a score of zero (0). Researchers reveal the formula used [16]. Here is the formula:

$$
\text { CSRDIj }=\frac{E x i j}{n j} X 100 \%
$$

3) Good corporate governance: GCG is a set of systems that regulate and control the company to create added value for stakeholders [17].

4) Financial performance: Financial performance can be regulated by return on assets (ROA). ROA was chosen as a proxy because this ratio serves to measure the company's effectiveness in generating finance by utilizing its assets. This proxy was chosen because it is the essential ratio among the current profitability ratios [18].

\section{ROA = Net Income after Tax / Total Assets}

\section{Population and Sample}

The population in this study are banking companies listed on the IDX. The sampling technique was carried out using purposive sampling, namely sampling with particular objectives or criteria so that 45 banking companies in Indonesia were listed on the IDX period 2012-2016.

\section{E. Technical Analysis and Hypotheses}

In this study, researchers used SPSS (Statistical Package for Social Science) to analyze data. This analysis begins with descriptive statistics and definitive assumption tests. This classic assumption test consists of a multicollinearity test, normality test, heteroscedasticity test, autocorrelation test. Moreover, the data collection was carried out by multiple 
regression analysis and hypothesis testing in the form of the coefficient of determination (R2), F test, and t-test.

\section{RESULTS AND DISCUSSION}

A. Data Analysis Test Results

1) Descriptive statistics

TABLE I. DESCRIPTIVE STATISTICS

\begin{tabular}{|l|l|l|l|l|l|}
\hline \multicolumn{7}{|c|}{ Descriptive Statistics } \\
\hline & N & Minimum & \multicolumn{1}{|c|}{ Maximum } & \multicolumn{1}{c|}{ Mean } & Std. Deviation \\
\hline IC & 65 & 109 & 494 & 283,60 & 100,129 \\
\hline CSR & 65 & 62 & 65 & 62,66 & 1,035 \\
\hline GCG & 65 & 1 & 3 & 1,92 & 478 \\
\hline ROA & 65 & 15 & 5,42 & 2,3783 & 1,33715 \\
\hline Valid N(listwise) & 65 & & & & \\
\hline
\end{tabular}

Based on the results of the calculations in table 1, it shows that the number of observations in this study was 13 Conventional Banking Companies that became the sample where the 13 companies were multiplied by the observation year period ( 5 years), so the observations in this study were 65 observations $(13 \times 5=65)$.

2) Classic assumption test

a) Normality test: The normality test aims to test whether there is a dependent variable in the regression model and an independent variable with a normal distribution or an abnormal distribution.

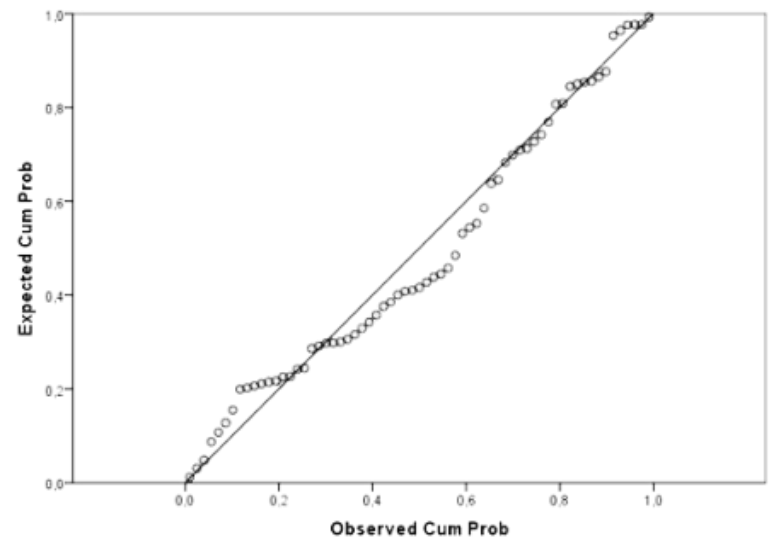

Fig. 1. Normal p-plot of standardized residual regression.

Source: processed data, 2019

Based on the results of the Normal P-Plot of Regression Standardized Residual test, it tells that the data distribution spreads around the diagonal line and follows the direction of the diagonal line, this indicates that the regression model fulfills the assumption of normality.

b) Multicollinearity test: The multicollinearity test aims to test whether the regression model found a correlation between independent variables (independent).
TABLE II. MULTICOLLINEARITY TEST RESULTS

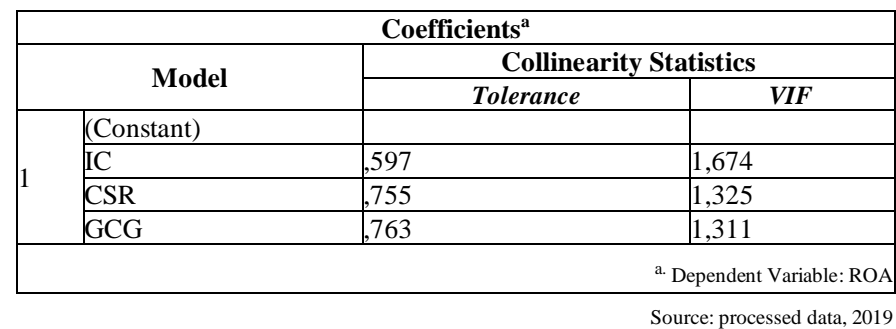

Based on the table 2 above, it shows that the multicollinearity test results, the tolerance value of each independent variable $>0.10$, while the VIF value $<10$. Thus, the result of this study did not occur multicollinearity in the regression model.

c) Autocorrelation test: The autocorrelation test determines the correlation between the residuals in observation and the regression model. If there is a correlation, then it is called there is an autocorrelation problem.

TABLE III. AUTOCORRELATION TEST RESUlts

\begin{tabular}{|l|c|l|l|l|l|}
\hline Model & R & R Square & $\begin{array}{c}\text { Adjusted R } \\
\text { Square }\end{array}$ & $\begin{array}{c}\text { Std. Error of the } \\
\text { Estimate }\end{array}$ & $\begin{array}{c}\text { Durbin- } \\
\text { Watson }\end{array}$ \\
\hline 1 &, $785^{\mathrm{a}}$ &, 616 &, 597 &, 84863 & 1,663 \\
\hline \multicolumn{3}{|r|}{ a. Predictors: (Constant), GCG, CSR, IC } \\
\hline \multicolumn{3}{|r}{ b. Dependent Variable: ROA } \\
\hline
\end{tabular}

Based on the results of the autocorrelation test, the DurbinWatson value is 1.663 . So that the DW value is between 1.55 to 2.46. It shows that there is no autocorrelation.

d) Heteroscedasticity test: To test the presence or absence of this heteroscedasticity is done by looking at the Scatter Plot, whether it spreads or shapes a specific pattern on its residuals.

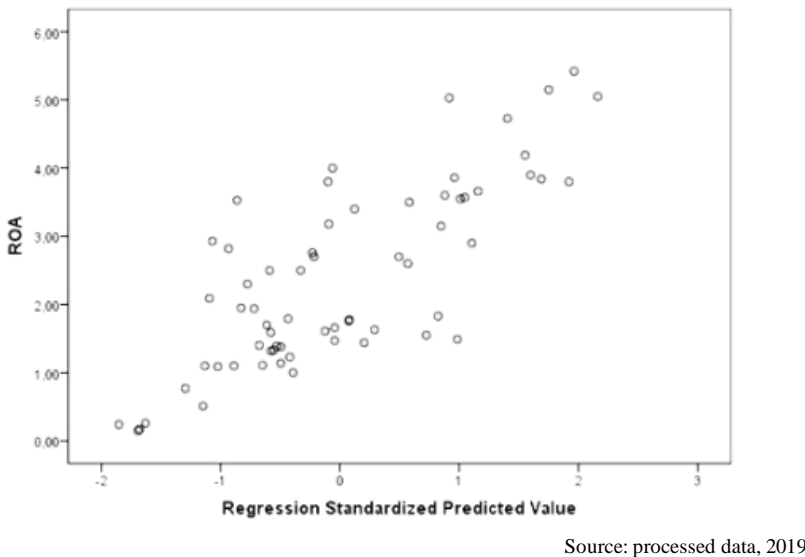

Fig. 2. Heteroscedaticity test results scatterplot dependent variable: ROA 
From Figure 2, the scatter plot shows that the dots are spread out randomly and there is no tendency to form a specific pattern, so there is no symptom of heteroscedasticity.

3) Multiple linear regression analysis: Multiple regression analysis examines the influence of IC, CSR, and GCG on ROA.

TABLE IV. MULTIPLE LINEAR REGRESSION ANALYSIS TEST RESUlTS

\begin{tabular}{|c|c|c|c|c|c|c|}
\hline \multicolumn{7}{|c|}{ Coefficients $^{\mathrm{a}}$} \\
\hline & \multirow[t]{2}{*}{ Model } & \multicolumn{2}{|c|}{$\begin{array}{l}\text { Unstandardized } \\
\text { Coefficients }\end{array}$} & \multirow{2}{*}{$\begin{array}{c}\begin{array}{c}\text { Standardized } \\
\text { Coefficients }\end{array} \\
\text { Beta } \\
\end{array}$} & \multirow[t]{2}{*}{$\mathbf{t}$} & \multirow[t]{2}{*}{ Sig. } \\
\hline & & $B$ & Std. Error & & & \\
\hline \multirow[t]{4}{*}{1} & (Constant) & 23,692 & 7,155 & & 3,311 &, 002 \\
\hline & IC &, 013 &, 001 & ‘974 & 9,487 &, 000 \\
\hline & CSR &,- 418 &, 118 &,- 324 & $-3,54$ &, 001 \\
\hline & GCG &, 628 &, 254 &, 224 & 2,471 &, 016 \\
\hline & \multicolumn{6}{|c|}{ a. Dependent Variable: ROA } \\
\hline
\end{tabular}

Source: processed data, 2019

Regarding the results of SPSS, a multiple regression equation can be made as follows:

$$
\mathrm{Y}=23.692+0.013 \mathrm{X} 1-0.418 \mathrm{X} 2+0.628 \mathrm{X} 3
$$

The multiple linear regression equation above means that:

- The constant is 23,692. It means that if IC, CSR, and GCG do not influence it, then the amount of Financial Performance (ROA) is 23,692 .

- The coefficient of the IC variable is 0.013. It means that if there is increasing in IC by oneunit, Financial Performance (ROA) will also increase by 0.013 , assuming other variables are constant.

- The CSR variable coefficient is -0.428. It means that if there is increasing in CSR by one unit, then the Financial Performance (ROA) will also increase by 0.428 with the assumption that other factors are constant.

- The variable coefficient of GCG is 0.628. It means that if there is an increase in GCG by one unit, the Financial Performance (ROA) will also decrease by 0.628 , assuming other variables are constant.

\section{4) Hypothesis}

a) Determination Coefficient Test $\left(R^{2}\right)$ : Test $\left(\mathrm{R}^{2}\right)$ calculates the level of closeness of the connection between the independent variable and the dependent variable.

TABLE V. R SQUARE TEST RESUlts

\begin{tabular}{|c|c|c|c|c|c|}
\hline \multicolumn{2}{|c|}{ Model } & $\mathbf{R}$ & R Square & $\begin{array}{c}\text { Adjusted R } \\
\text { Square }\end{array}$ & $\begin{array}{l}\text { Std. Error of } \\
\text { the Estimate }\end{array}$ \\
\hline dimension0 & 1 &, $785^{\mathrm{a}}$ &, 616 &, 597 &, 84863 \\
\hline
\end{tabular}

In the table above, it is known that the correlation coefficient $\mathrm{R}$ is 0.785 or close to 1 . It means that there is a strong correlation between the independent variables, which includes IC, CSR, and GCG on the dependent variable, namely Financial Performance (ROA)

As for the multiple determination analysis, from the table above, it is known that the percentage of the influence of the independent variable on the dependent variable aimed at the $\mathrm{R}$ square value is 0.616 , the coefficient of multiple determination is $0.616 \times 100 \%=61.6 \%$ and the rest is $100 \%-61.6 \%=38.4$ $\%$. It means that the rise and fall of the dependent variable, namely Financial Performance (ROA), is influenced by the independent variables, i.e., IC, CSR, and GCG of $61.6 \%$. Simultaneously, the remaining $38.4 \%$ is influenced by other variables not examined in this study.

b) Simultaneous Test (Test F): The F test is used to measure the level of influence of significance together (simultaneously).

TABLE VI. Simultaneous 'Test Result' (Test F)

\begin{tabular}{|c|c|c|c|c|c|c|}
\hline & Model & $\begin{array}{c}\text { Sum of } \\
\text { Squares }\end{array}$ & df & $\begin{array}{c}\text { Mean } \\
\text { Square }\end{array}$ & $\mathbf{F}$ & Sig. \\
\hline \multirow[t]{3}{*}{1} & Regression & 70,500 & 3 & 23,500 & 32,631 & $000^{\mathrm{a}}$ \\
\hline & Residual & 43,931 & 61 &, 720 & & \\
\hline & Total & 114,431 & 64 & & & \\
\hline \multicolumn{7}{|c|}{ a. Predictors: (Constant), GCG, CSR, IC } \\
\hline & & & & & \multicolumn{2}{|c|}{ b. Dependent Variable: ROA } \\
\hline
\end{tabular}

Based on the table 6 above, it shows that the F significance value is 0.000 , which means this number is much smaller than 0.05 , and the calculated $\mathrm{f}$ value is 32.631 and $\mathrm{f}$ table 2.76. Because the calculated $f$ value is greater than the $\mathrm{f}$ table, which is 32.631> 2.76 with a significant level of $0.000<0.05$, the conclusion is that IC, CSR, and GCG together have an effect on Financial Performance (ROA) in banking companies.

c) The T-test (partial test): The t-test measures the level of partial significance of influence between the independent variables, which include IC, CSR, and GCG on Financial Performance (ROA) in banking companies.

TABLE VII. PARTIAL TEST RESUlts (T-TEST)

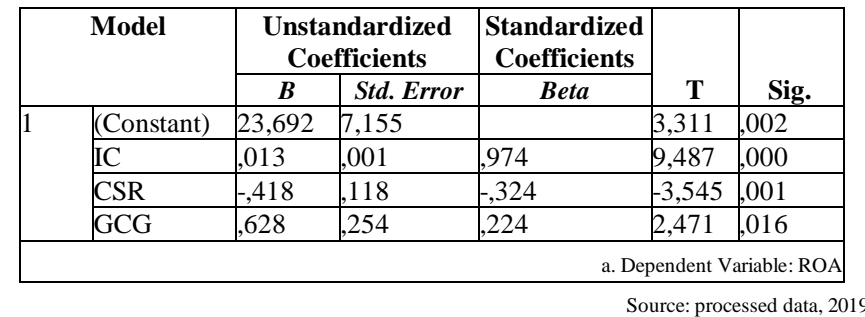

Thus, the test results can be concluded that: 
TABLE VIII. TEST RESULT

\begin{tabular}{|c|c|c|c|}
\hline No. & Explanation & Result & Notes \\
\hline 1 & $\begin{array}{l}\text { Hypothesis 1: } \\
\text { IC has a significant effect } \\
\text { on Financial Performance } \\
\text { (ROA) }\end{array}$ & Accepted & $0,000<0,05$ \\
\hline 2 & $\begin{array}{l}\text { Hypothesis 2: } \\
\text { CSR has a significant } \\
\text { effect on Financial } \\
\text { Performance (ROA) }\end{array}$ & Accepted & $0,001<0,05$ \\
\hline 3 & $\begin{array}{l}\text { Hypothesis 3: } \\
\text { GCG has a significant } \\
\text { effect on Financial } \\
\text { Performance (ROA) }\end{array}$ & Accepted & $0,016<0,05$ \\
\hline 4 & $\begin{array}{l}\text { Hypothesis 4: } \\
\text { IC, CSR, and GCG have a } \\
\text { simultaneous effect on } \\
\text { Financial Performance } \\
\text { (ROA) }\end{array}$ & Accepted & $0,000<0,05$ \\
\hline
\end{tabular}

\section{B. Discussion}

1) The Influence of Intellectual Capital (IC) on Financial Performance (ROA) in Banking Companies: The IC variable Multiple Linear Regression test results in the banking company for 2012-2016 showed a significance level of 0.000 below the $0.05(5 \%)$ level. Thus, the IC hypothesis affects financial performance (ROA) is accepted and affects the company in financial performance (ROA). The results of this test can support the hypothesis.

The results indicated that the company's intellectual capital had been used and developed to its full potential. It can be seen from the results of the VAIC component (Value Added Intellectual Coefficient), and VAHU (Value Added Human Capital) has the highest average value of $386 \%$. It shows that the relationship between VA and $\mathrm{HC}$ (the ability to create $\mathrm{HC}$ values in a company) is maximally used and developed. Compared to VACA and STVA. The results of the VACA (Value Added Capital Employed) component have the highest average value of $47 \%$. It shows that the VA is created by one unit of physical capital. Meanwhile, STVA (Structural Capital Value Added) has the highest average value of $74 \%$. It shows the contribution of structural capital (SC) in value creation. This study supports the research of Hermawan and Mardiyanti [19], Sriwahyuni et al. [20], Ting and Lean [21], Mehri et al. [22], Rachmawati et al. [23], Hermawan [24], Soewarno and Tjahjadi [25] which states that IC has an effect on ROA. However, this study is different from the research by Hermawan and Wahyuaji [26] which states that IC has a negative effect on ROA. This is due to the large IC which is assessed based on employee expenses is not a guarantee of the amount productivity of the workforce. There is an increase in employee expenses without an increase in work productivity makes IC have a negative effect on ROA, because the cost of employee increases but the net profit is not indicates a meaningful change.

2) Influence Corporate Social Responsibility (CSR) to Financial Performance (ROA) at Banking Companies: Based on the results of statistical tests, it shows that Corporate Social
Responsibility (CSR) affects the company's financial performance (ROA). It can be proven by looking at the statistical results, which show the probability significance level of 0.001 . Because the probability significance level is less than 0.05 , the conclusion is that the second hypothesis is accepted. It means that Corporate Social Responsibility (CSR) affects the Company's Financial Performance (ROA).

The existence of Law No. 40 of 2007 also encourages activities to broaden Corporate Social Responsibility and is implemented compulsorily (mandatory) and no longer voluntary (Voluntary). In other words, the company's current management should realize that Corporate Social Responsibility is not just an activity but is an obligation for the company to survive and maintain the company's survival. The company also understands the benefits will receive in the future, such as building the company's reputation, which will benefit the company's economic value, such as increasing its share price, obtaining established and potential investors, which motivates the company to carry out activities. The results of this study support the research conducted by Dkhili and Ansi [27] but does not support research by Matuszaka and Różańskaa [28].

3) Influence Good Corporate Governance (GCG) on Financial Performance (ROA) in Banking Companies: Based on the results of statistical tests show that Good Corporate Governance affects the company's financial performance (ROA). It can be proven by looking at the statistical results, which show a probability significance level of 0.016 . Because the probability significance level is less than 0.05 , the conclusion is that the third hypothesis is accepted. It means that Good Corporate Governance affects the Company's Financial Performance (ROA).

Good Corporate Governance with a measurement mechanism is that managerial ownership will lead to an assumption that the higher the managerial ownership will increase the company's financial performance. Theoretically, a Good Corporate Governance system can improve their financial performance, reduce risks that the board may carry out with positive decisions. Generally, Good Corporate Governance can increase investors' confidence to invest, which will impact the company's financial performance. The results of this study support the research conducted by Mahrani and Soewarno [29], Kumalasari and Pratikto [30], Rostamia et al. [31].

4) Influence Intellectual Capital (IC), Corporate Social Responsibility (CSR), and Good Corporate Governance (GCG) on Financial Performance (ROA) in Banking Companies: Based on the results of hypothesis testing that has been done, it is found that IC, CSR, and GCG have a joint influence on the company's financial performance. The company performance is influenced by several factors, including ownership concentration or non-concentration, earnings manipulation, and disclosure of financial statements. A company with management that implements a good 
management system will provide protection and guarantee rights to the stakeholders.

Therefore, management is required to provide accurate information about the actual condition of the company. A company's accomplishment will depend on a transformation, invention, and capitalization of the company's knowledge itself or commonly known as intellectual capital. The company's reason for using the sustainability reporting framework (in this case CSR) is to communicate management performance to achieve long-term company benefits to stakeholders, such as improved financial performance and competitive advantage, increased profits, and long term.

Intellectual working capital includes all knowledge of employees, their organization, and their ability to create added value and lead to sustainable competitive advantage. Suppose the company is successful in managing intellectual capital. In that case, it can improve the company's performance so that later it can affect the company's value that will be seen by investors and society in general. It is the same as carrying out Corporate Social Responsibility activities. With the existence of Corporate Social Responsibility, the company will be seen as a company with a high social spirit, so investors as stakeholders will be more interested in investing in the company. The more investment that comes in, the company's income will increase. Besides, Good Corporate Governance can be explained that the more members of the board of commissioners will affect performance in the company. This study simultaneously shows that members of the board of commissioners can play a role and carry out their functions properly in providing control and monitoring for management in carrying out company operations. Good Corporate Governance will affect the company's performance so that investors will be interested in investing.

\section{CONCLUSION}

This study examines the company's financial performance, which is influenced by IC, CSR, and GCG. The analysis is using multiple linear regression using SPSS 18. The research sample data were 13 banking companies listed on the Indonesia Stock Exchange (BEI) in 2012-2016.

Based on the results of testing and discussion in the previous section, it can be concluded as follows:

- Intellectual Capital has a partial effect on financial performance in banking companies listed on the IDX.

- Corporate Social Responsibility Partially influences financial performance in banking companies listed on the IDX.

- Good Corporate Governance has a partial effect on financial performance in banking companies listed on the IDX for the period.

- Intellectual capital, Corporate Social Responsibility, and Good Corporate Governance have a simultaneous influence on financial performance in banking companies listed on the IDX.

\section{ACKNOWLEDGMENT}

Thanks to Universitas Muhammadiyah Sidoarjo, Indonesia

\section{REFERENCES}

[1] S. Hermawan, W. Hariyanto, and S. Biduri, "Intellectual Capital, Business Performance, and Competitive Advantage: An Empirical Study for the Pharmaceutical Companies," Quality Access To Success, Vol 21 , No 175, April, 2020.

[2] S. Hermawan, E. Nurasik, D. Rahayu, and I.D. Rahmawati, "Intellectual Capital Disclosure and Company Financial Performance: Market Capitalization, Vol. 13, Issues 7, 2020.

[3] S. Hermawan and S. Herlina, "Studi Intepretif Identifikasi dan Interaks Intellectual Capital terhadap Kinerja Perusahaan,” Jurnal Reviu Akuntansi Dan Keuangan, Vol. 3, No. 1, April. 2013.

[4] P.Z. Mageza, Intellectual Capital As A Creator of Wealth and Shareholder Value For An Organization. Short Dissertation. Rand Afrikaans University, 2004

[5] R.C. Tumewu and S.W. Alexander, Pengaruh Good Corporate Governance Terhadap Profitabilitas Pada Perusahaan Perbankan yang Terdaftar di BEI Periode 2009-2013, Manado: Program Pendidikan Profesi Akuntansi Fakultas Ekonomi dan Bisnis Universitas Sam Ratulangi Manado, 2014, p. h.2.

[6] J. Elkington, Canibal With Forks: The Triple Bottom Line of 21st Century Business. Oxford: Capstone Publishing Lt, 2010.

[7] H. R. Bowen, Social Responsibility Of The Businessman. NewYork: Harper and Brothers, 1953.

[8] D. Elvinaro, Handbook of Public Relations, Bandung: Simbiosa Rekatama Media, 2011

[9] D. Rachmawati, "Pengaruh Intellectual Capital Terhadap Return On Asset (ROA) Perbankan,” Jurnal Akuntansi, vol. 1, p. 1, 2012.

[10] G. Kamath, “The Intellectual Capital Performance of Indian Banking Sektor," Journal of Intellectual Capital, pp. 96-123, 2007.

[11] T.E. Copeland and J.F. Weston, Manajemen Keuangan, Edisi 8. Jilid I. Alihbahasa: Jaka Wasana dan Kirbrandoko. Jakarta: Gelora Aksara Pratama, 1995

[12] S. Hermawan and Amirullah, Metodologi Penelitian Bisnis Pendekatan Kuantitatif Dan Kualitatif. Malang: Cetakan Pertama. Media Nusa Creative, 2016.

[13] V.W. Sujarweni, Metodologi Penelitian Bisnis \& Ekonomi. Yogyakarta: PUSTAKABARUPRESS, 2015.

[14] A. Gozali and E.H. Saarce, "Pengaruh Intellectual Capital Terhadap Kinerja Keuangan Dan Nilai Perusahaan Khususnya Di Industri Keuangan Dan Industri Pertambangan Yang Terdaftar Di Bursa Efek Indonesia Tahun 2008-2010," Business Accounting Review, vol. 2 2014.

[15] Pulic, Ante. VAICTM an accounting tool for IC management International Journal of Technology Management, Vol. 20, No. 5, January 2000 .

[16] Y.A. Bhernadha, T. Topowijono, and D.F. Azizah, "Pengaruh Corporate Social Responsibility Terhadap Kinerja Keuangan Perusahaan," Jurnal Administrasi Bisnis, Universitas Brawijaya, Maret 2017.

[17] M.A. Effendi, The Power of Good Corporate Governance: Teori dan Implementasi. Jakarta: Salemba Empat, 2009.

[18] J.J. Jewell and J.A. Mankin, "What Is Your ROA? An Investigation Of The Many Formulas For Calculating Return On Assets," Academy of Educational Leadership Journal, Vol. 15, Special Issue, 2011. 
[19] S. Hermawan and U.I. Mardiyanti, "Intellectual Capital dan Kinerja Keuangan Perusahaan High IC Intensive. BENEFIT,” Jurnal Manajemen dan Bisnis, Vol. 1, No. 1, Juni 2016, pp. 70-78.

[20] D. Sriwahyuni, S. Hermawan, and N.R. Hanun, "Intellectual Capital Terhadap Kinerja Keuangan Perusahaan Farmasi Di Indonesia," Jurnal eBA, Vol. 5, No. 1, Februari 2019.

[21] I.W.K. Ting and H.H. Lean, "Intellectual Capital Performance of Financial Institutions in Malaysia," Journal of Intellectual Capital, Vol. 10 No. 4, pp. 588-599, 2009.

[22] M. Mehri, M.S. Umar, P. Saeidi, R.K. Hekmat, and Naslmosavi, S. (2013). Intellectual capital and firm performance of high intangible intensive industries: Malaysia evidence. Asian Social Science, 9(9), 146.

[23] E.N. Rachmawati, R. Hayati, and F. Yulandi, "The Influence of Intellectual Capital on Financial Performance in Sharia Banking Companies," Advances in Social Science, Education and Humanities Research (ASSEHR), volume 186 15th. International Symposium on Management (INSYMA 2018)

[24] S. Hermawan, "Intellectual Capital, Financial Performance and Market Performance : Evidence From High IC Intensive Company in Indonesia" Jurnal Dinamika Akuntansi, vol. 11, no. 2, pp 98-107, dec 2019

[25] N. Soewarno and B. Tjahjadi, "Measures that matter: an empirical investigation of intellectual capital and financial performance of banking firms in Indonesia,” Journal of Intellectual Capital, Vol. June 2020.
[26] S. Hermawan and M. Wahyuaji, “Analisis Pengaruh Intellectual Capita Terhadap Kemampulabaan Perusahaan Manufaktur Consumer Goods Di Bursa Efek Indonesia,” Proseding. Seminar Nasional dan Call For Paper 2013.

[27] H. Dkhili and H. Ansi, "The Link between Corporate Social Responsibility and Financial Performance: The Case of the Tunisian Companies," Journal of Organizational Knowledge Management, Vol. 2012 .

[28] L. Matuszaka and E. Różańskaa, "An examination of the relationship between CSR disclosure and financial performance: The case of Polish banks," Accounting and Management Information Systems, Vol. 16, No. 4, pp. 522-533, 2017.

[29] M. Mahrani and N. Soewarno, "The Effect of Good Corporate Governance Mechanism And Corporate Social Responsibility on Financial Performance with Earnings Management As Mediating Variable," Asian Journal of Accounting Research, Vol. 3 No. 1, pp. 4160, 2018.

[30] D. Kumalasari and H. Pratikto, "Good Corporate Governance Affects on Corporate Value Through Return on Equity and Return on Asset of Manufacture Company, KnE Social Sciences, 114-126.

[31] S. Rostamia, Z. Rostamib and S. Kohansala, "The Effect of Corporate Governance Components on Return on Assets and Stock Return of Companies Listed in Tehran Stock Exchange," Procedia Economics and Finance 36, 137 - 146, 2016. 